\title{
Self-inflicted specific pattern burns in psychiatric patients
}

\author{
Chenicheri Balakrishnan MD, Venkata S Erella MD, Christopher Vashi MD, Ollie Jackson MD, Shawn Vandemark MD
}

\begin{abstract}
C Balakrishnan, VS Erella, C Vashi, O Jackson, S Vandemark. Self-inflicted specific pattern burns in psychiatric patients. Can J Plast Surg 2007;15(3):153-154.
\end{abstract}

Self-inflicted burns represent a major social and medical problem for society. Differences have been demonstrated between patients who attempt suicide and those who deliberately harm themselves without any intention of killing themselves. These self-inflicted injuries may resemble injuries that are intentionally inflicted by others and may require investigation by protective services. Little is known about these specific pattern burn injuries in psychiatric patients.

\section{Types de brûlures auto-infligées chez les patients atteints d'une maladie mentale}

Les brûlures auto-infligées constituent un important problème social et médical. D'après des études, il existe des différences entre les patients qui tentent délibérément de se suicider et ceux qui tentent à dessein de s'automutiler sans toutefois vouloir se suicider. Ce genre de sévices auto-infligés peuvent ressembler à de mauvais traitements infligés par d'autres personnes et, ainsi, nécessiter la tenue d'une enquête par les services de protection. On connaît peu de choses sur les types particuliers de brûlures observés chez les patients atteints d'une maladie mentale.

Key Words: Specific pattern burns

Tntentional suicide and self-mutilation without suicidal intent by burning are puzzling injuries that require psychiatric treatment in addition to burn care. Self-inflicted injuries are often seen in patients with a borderline personality disorder who scratch or burn themselves repeatedly. Their dysfunctional behaviour patterns present specific challenges to the caregiver. We present three patients with a history of schizophrenia who presented with self-inflicted specific pattern injuries.

\section{Case 1}

\section{CASE PRESENTATIONS}

A 55-year-old man with a 10-year history of chronic schizophrenia presented with burns to the buttocks. He had been institutionalized intermittently for his psychiatric illness. His medical history was significant for duodenal ulcer, and his medications included clonazepam, lithium carbonate, atenolol and diphenhydramine.

Physical examination revealed a withdrawn man who appeared older than his stated age. He responded tersely and somewhat reluctantly to questions. He had symmetrical deep burns involving both the buttocks (Figure 1). According to his cousin, he had been found sitting in the bathtub in very little water, holding on to the sides of the bathtub.

\section{Case 2}

A 41-year-old man presented with burns to both buttocks and lower extremities. There was sparing of the centre part of the buttocks (Figure 2). According to the family, he attempted suicide by sitting in a bathtub and running hot water. There was a line demarcating the area exposed to hot liquid. He had a long history of schizophrenia and was institutionalized for his disease. He had a history of gallstones and self-inflicted wounds to his wrist. He was taking lithium carbonate and clonazepam. In this patient, the central part of the buttocks

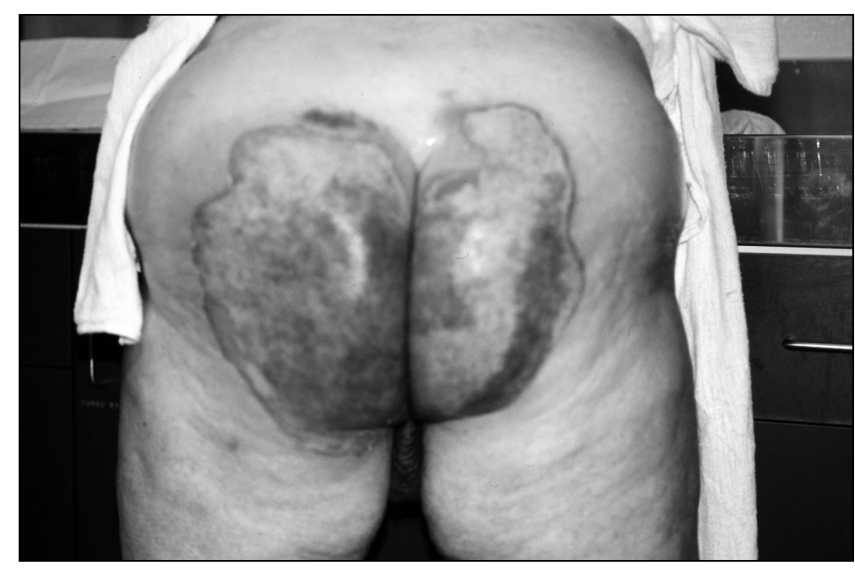

Figure 1) Patient 1: burns of the buttocks

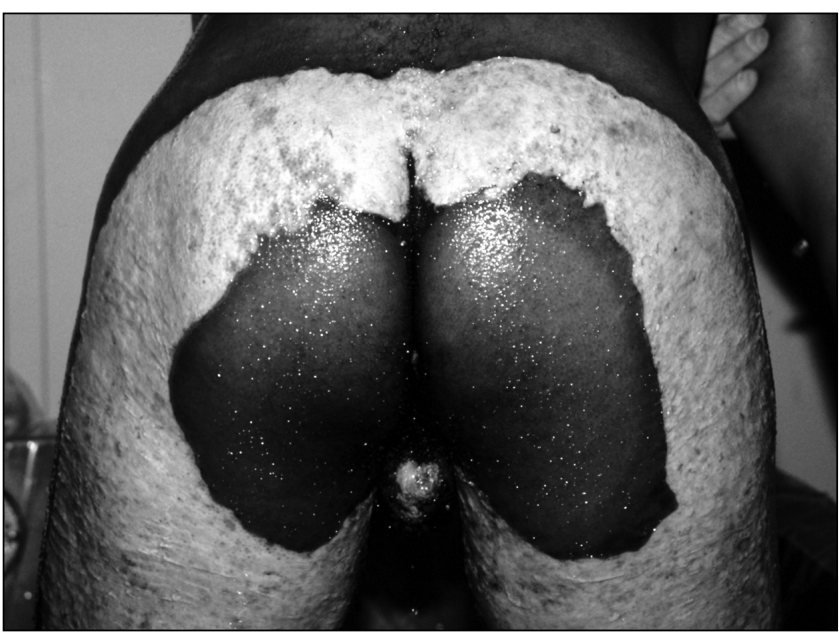

Figure 2) Patient 2: burns to both buttocks and lower extremities, with sparing of the central buttocks 


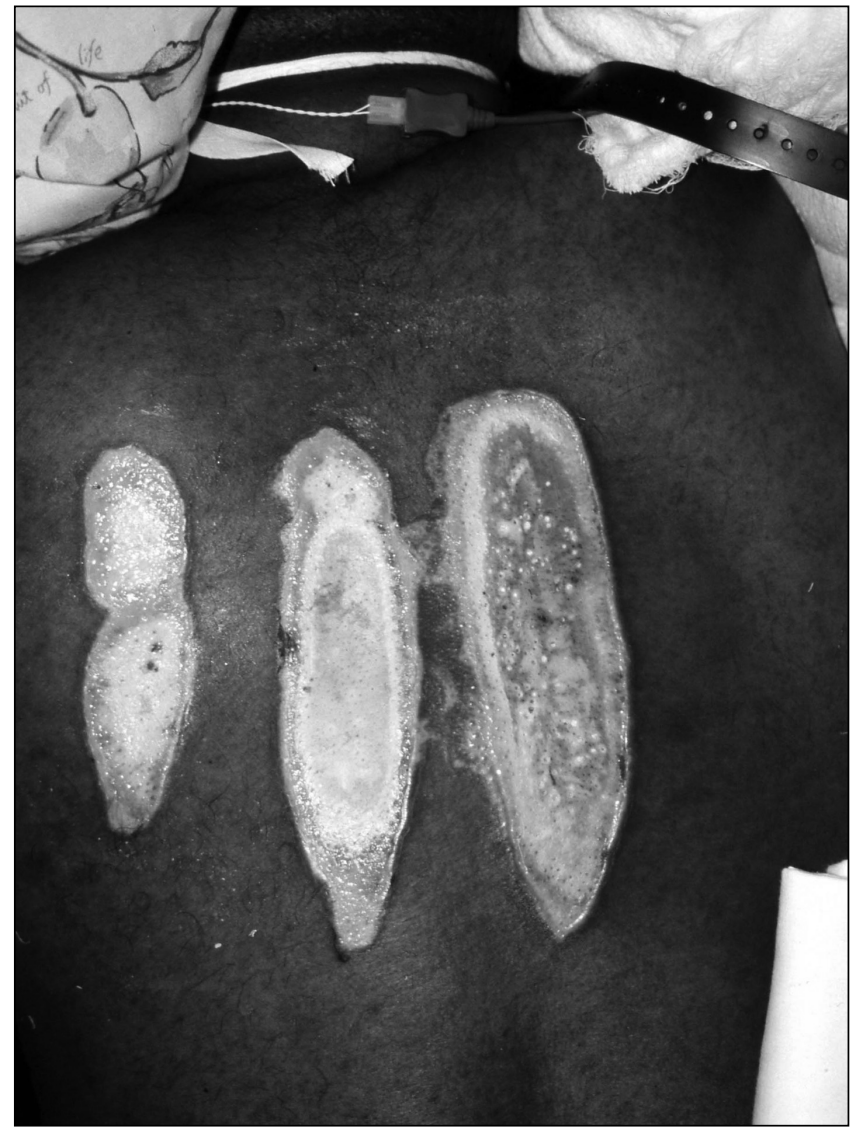

Figure 3) Patient 3: linear burns to the back from contact with a hot water pipe inside a closet

was spared because he sat in the bathtub before running the water.

\section{Case 3}

A 39-year-old man presented with burns over his upper back. He had three linear deep burns (Figure 3), which were presumably contact burns. His caregiver found his clothes soiled with exudates and brought him to the hospital. His past history was significant for attempted suicide, depression and narcolepsy. His surgical history included multiple laparotomies for intestinal obstruction from foreign body ingestion and lysis of adhesions; he was institutionalized for violent behaviour, and was considered to be a threat to himself and to the public.

\section{REFERENCES}

1. Stone NH, Rinaldo L, Humphrey CR, Brown RH. Child abuse by burning. Surg Clin North Am 1970;50:1419-24.

2. Lenoski EF, Hunter KA. Specific patterns of inflicted burn injuries. J Trauma 1977;17:842-6.

3. Tuohig GM, Saffle JR, Sullivan JJ, Morris S, Lehto S. Self-inflicted patient burns: Suicide versus mutilation. J Burn Care Rehabil 1995;16:429-36.

4. Wiechman SA, Ehde DM, Wilson BL, Patterson DR. The management of self inflicted burn injuries and disruptive behavior
Physical examination revealed a socially withdrawn man who refused to answer questions. Because the injury happened in a psychiatric institution, the incident was investigated and found to be a self-inflicted burn from contact with a hot water pipe inside a closet.

\section{DISCUSSION}

Certain injury patterns are considered to be telltale signs of abuse. This is useful in detecting abuse in children. Immersion burns have well-demarcated skin areas, which allow one to determine the position of the individual at the time of injury. Specific pattern burns are often symmetrical and appear to be full thickness in depth, suggesting that the extremities were immersed and held in hot liquid (1). Forced immersion burns usually show a central area of sparing due to part of the body being compressed against the sides or bottom of the container, thereby avoiding exposure of the compressed area to the hot liquid (2).

Attempted suicide can result from interaction of factors such as isolation, loneliness, hopelessness and failure to adapt, as well as mental health disorders such as depression. In suicidal patients, self-inflicted flame burns are usually severe, and accelerents have been used. Burn size is smaller in patients who mutilate themselves with no intent of suicide than in suicidal patients. These patients usually have a previous history of a psychiatric disorder. Self-mutilating patients have a higher incidence of personality disorders, while there is a higher incidence of depression noted in people who have attempted suicide (3). Parasuicidal behaviour is defined as intentional self-injurious behaviour that, although not fatal, may result in tissue damage or risk of death. Borderline personality disorder is considered to be the reason for this type of behaviour (4). Reports have shown larger and deeper injuries in patients who attempt suicide by burning. Although a similar mortality rate to the predicted mortality rate has been reported in some studies (5), a higher mortality rate has been reported in patients with a previous history of self-harm or suicide attempts (6).

Self-inflicted specific pattern burns are rare (7). In the present three cases, there were previous attempts of self-mutilation. Because these injuries resemble forced immersion burns, investigation by protective services was required to rule out foul play. Management of such patients should include treatment of the burn injuries and psychosocial evaluation. During the recovery phase, patients with suicidal ideation should be adequately monitored and regularly followed by appropriate mental health professionals.

for patients with borderline personality disorder. J Burn Care Rehabil 2000;21:310-7.

5. Rasheed A, Gower JP. A review of the trends of self inflicted burns. Burns 2004;30:573-6.

6. Wallace KL, Pegg SP. Self-inflicted burn injuries: An 11-year prospective study. J Burn Care Rehabil 1999;20:191-4.

7. Balakrishnan C, Greer KA, Tse KG, Hardaway MY. Specific pattern burn in a psychiatric patient. Burns $1993 ; 19: 439-40$ 